\title{
Potential of selected fungi for biological stump removal of Eucalyptus spp.
}

\author{
Lais Gonçalves da Costa ${ }^{\mathrm{a}, *}$, Juarez Benigno Paes ${ }^{\mathrm{a}}$, Waldir Cintra de Jesus Junior ${ }^{\mathrm{b}}$, \\ Victor Fassina Brocco ${ }^{a}$, Edson Luiz Furtado ${ }^{c}$ \\ a Department of Forest and Wood Science, Federal University of Espírito Santo, Governador Lindemberg, 316, 29550-000 Jerônimo Monteiro, Espírito Santo, Brazil \\ b Lagoa do Sino Academic Department, Federal University of São Carlos, Aracaçu, 18290-000 Buri, São Paulo, Brazil \\ c Department of Vegetal Protection, College of Agronomic Sciences, São Paulo State University, Doutor José Barbosa de Barros, 1780, 18610-307 Botucatu, São Paulo, \\ Brazil
}

\section{A R T I C L E I N F O}

\section{Keywords:}

Fungi selection

Stump decay

Wood chemistry

Wood-decaying fungi

\begin{abstract}
A B S T R A C T
This study aimed to evaluate the decay potential of fungi isolated from plantations of Eucalyptus spp. for biological stump removal. Therefore, an accelerated decay test was performed with fungi isolated from stumps of Eucalyptus spp.: Phanerochaete chrysosporium, Cladosporium sp., Penicillium sp., Penicillium implicatum, Resinicium confertum, Trichoderma citrinoviride and Acremonium sp. Chemical analysis of the decayed wood was performed on samples submitted to the most degrading fungi. A field test on eucalyptus stumps, with two methods of inoculation and covering, was performed to evaluate the stumps deterioration by the isolated fungi. Acremonium sp., Cladosporium sp. and P. chrysosporium showed the highest potential in the accelerated decay test. Chemical analysis of the decayed wood indicated the selectivity of fungi for lignin. No significant variations were observed in the field test compared to the control stumps. Biological stump removal shows both environmental and economic potential and needs to be thoroughly studied.
\end{abstract}

\section{Introduction}

Plantations of Eucalyptus spp. in Brazil have been increasing in recent years. According to the Brazilian Tree Industry - IBÁ (2016), the Gross Domestic Product (GDP) of the Brazilian planted tree industry grew by $3 \%$ in 2015 , representing $1.2 \%$ of all of the wealth generated in the country. Eucalyptus plantations represent $72 \%$ of the total area of planted trees.

The multiple uses of eucalyptus wood are one of the factors that contributed to this increase because this wood can be used by the building, furniture, pulp and paper and energy industries. According to Andrade et al. (2012), fast growth and short rotations have consolidated the genus as a wood supply source.

With the increasing development of the planted tree industry, it is necessary to update the techniques that are used during the exploitation of forest plantations to produce less expensive and more eco-friendly alternatives. The removal of stumps of Eucalyptus spp. after harvesting is generally performed by a mechanical process. This process is costly and generates environmental damage, such as soil compaction and displacement of the soil organic layer, and there are also some areas that are not easily accessible, which makes mechanical stump removal difficult. Moreover, damage to machine parts and implements can occur (Dias and Arroja, 2012; Dedecek and Gava, 2005; Alonso et al., 2007;

\section{Coder, 2014).}

Thus, biological stump removal appears to be a promising alternative to mechanical stump removal (Silva et al., 2010; Negrão et al., 2014). However, the natural process of biological degradation of stumps is slow. For several years, such material remains unchanged, making the use of this process unfeasible (Coder, 2014).

On the other hand, according to Andrade et al. (2012), the use of selected fungi significantly increases the degradation of stumps of $\mathrm{Eu}$ calyptus spp. Moreover, this process leads to a reduction in nutrient export, microbiota maintenance and a reduction in the negative impacts on soil, thus contributing to the sustainability of planted forests (Alonso et al., 2007).

Among the fungi with this potential, wood-decaying fungi present the greatest potential for use. Known as white-, brown- and soft-rot fungi, they are responsible for the majority of wood decay and use enzymatic and non-enzymatic systems to degrade cellulose, hemicellulose and lignin of the wood cell wall (Zabel and Morrell, 1992; Schmidt, 2006; Tian et al., 2010; Ryss et al., 2011; Bari et al., 2015).

Therefore, according to the aforementioned factors, selection of fungi that accelerate the natural decay process of stumps that remain after forest extraction is very important. Thus, this study aimed to evaluate the decay potential of fungi isolated from plantations of Eucalyptus spp. for biological stump removal.

\footnotetext{
* Corresponding author.

E-mail address: lais-costa1@live.com (L.G.d. Costa).
} 


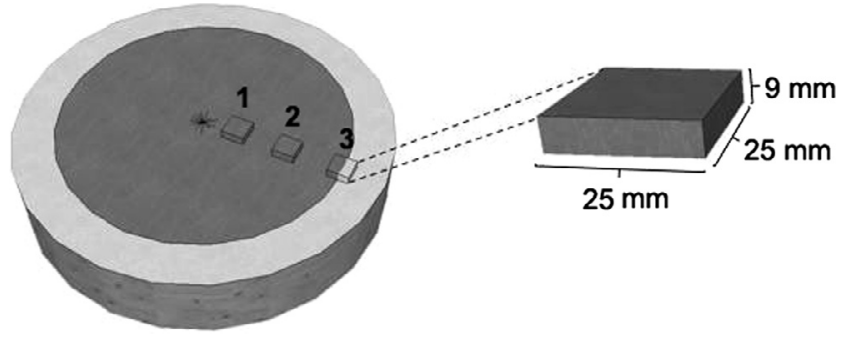

Fig. 1. Wood positions from which samples were obtained and their respective dimensions. Key: 1: inner heart wood; 2: middle heartwood; 3: heartwood-sapwood boundary.

Table 1

Degradation class of decay fungi..

Source: Adapted from ASTM D - 2017 (2005)

\begin{tabular}{lll}
\hline Mass loss (\%) & Residual mass (\%) & Class of degradation \\
\hline $0-10$ & $90-100$ & Slightly degrading \\
$11-24$ & $76-89$ & Moderately degrading \\
$25-44$ & $56-75$ & Degrading \\
$\geq 45$ & $\leq 55$ & Highly degrading \\
\hline
\end{tabular}

\section{Material and methods}

\subsection{Accelerated decay test with the isolated fungi}

To evaluate the deterioration capabilities fungi, an accelerated decay test using clonal Eucalyptus grandis $\mathrm{x}$ urophylla wood was conducted following the American Society for Testing and Materials ASTM D2017 (2005). Fungi isolated from Eucalyptus spp. stumps, Phanerochaete chrysosporium, Cladosporium sp., Penicillium sp., Penicillium implicatum, Resinicium confertum and Trichoderma citrinoviride, were used. The fungi Acremonium sp., isolated by Silva et al. (2014) and cited as basidiomycete 1 , was also used.

The isolated fungi were collected in three cities of Espírito Santo State, Brazil: Cachoeiro de Itapemirim $\left(20^{\circ} 46^{\prime} 19^{\prime \prime} \mathrm{S}, 41^{\circ} 18^{\prime} 07^{\prime \prime} \mathrm{W}\right.$, $100 \mathrm{~m}$ ), São José do Calçado (20 $\left.55^{\prime} 47^{\prime \prime} \mathrm{S}, 41^{\circ} 37^{\prime} 47^{\prime \prime} \mathrm{W}, 590 \mathrm{~m}\right)$ and Jerônimo Monteiro ( $20^{\circ} 51^{\prime} 43^{\prime \prime} \mathrm{S}, 41^{\circ} 27^{\prime} 32^{\prime \prime} \mathrm{W}, 800 \mathrm{~m}$ ), as described by Costa (2014). These fungi were taxonomically classified at the Plant Pathology Department, Seed Pathology and Post-Harvest Laboratory, Federal University of Viçosa, Viçosa-MG, Brazil.

The brown-rot fungi Gloeophyllum trabeum (Pers.) Murrill (Madison 617) and Postia placenta (Fr.) M.J. Larsen \& Lombard (Madison 698) as well as the white-rot fungus Polyporus fumosus (Pers.) Fr. (Forintek Canada Corp. 469 A) were compared to the isolated fungi due to their recognized decay potential.

According to ASTM D2017 (2005) procedures, wood samples with dimensions of $2.5 \times 2.5 \times 0.9 \mathrm{~cm}$ (radial $\times$ tangential $\times$ longitudinal) were prepared in three pith-bark positions: at the heartwood-sapwood boundary and at the middle and inner heartwood (Fig. 1). The test was maintained in a climate controlled room $\left(25 \pm 2{ }^{\circ} \mathrm{C}\right.$, with $65 \pm 5 \%$ relative humidity) for 12 weeks. After 12 weeks, the mass loss was evaluated and compared with the values shown in Table 1.

\subsection{Chemical analysis}

Chemical analysis of decayed wood was performed with the samples submitted to the most degrading fungi, which were selected in the accelerated decay test. The wood samples were transformed into sawdust following the Technical Association of Pulp and Paper Industry - TAPPI 257 om-92 (1992). Sawdust of wood samples not submitted to fungi attack was used as a control.

For the determination of extractives, $2 \mathrm{~g}$ of air-dried sawdust was submitted to a sequence of extractions in ethanol:toluene (1:2), ethanol, and hot water according to TAPPI T264 om-88 (TAPPI, 1996). Klason and acid soluble lignins were measured according to Gomide and Demuner (1986) and Goldschimid (1971), respectively. The total lignin was obtained from the sum of the Klason and acid soluble lignins. The holocellulose content was obtained by the difference of extractives and total lignin.

\subsection{Deterioration of stumps by isolated fungi}

A field test was conducted in a 7-year-old Eucalyptus grandis $\times$ urophylla plantation located in Providência a rural area of

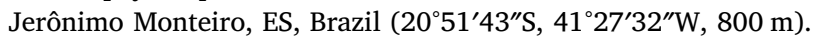

To verify the decay potential in stumps, the seven isolated fungi were employed. Thus, the remaining stumps from the first harvest without visual signs of fungal colonization were used. The trees of the remaining stumps were harvested 10 days before the field test.

In a laminar flow cabinet, fungal solutions were prepared using liquid culture media ( $20 \mathrm{~g}$ of malt extract in $1 \mathrm{~L}$ of sterile distilled water). For each solution, fractions of $50 \mathrm{~mL}$ of the fungus developed in Petri dishes were added. The fungal solutions were stored in a climate controlled room $\left(25 \pm 2{ }^{\circ} \mathrm{C}\right.$, with $65 \pm 5 \%$ relative humidity) for a period of 15 days to allow mycelial growth. Afterwards, the solutions were homogenized on a magnetic stirrer and used for the field test.

Two fungal inoculation methods were tested: spraying and inoculation by drilling the stumps. For each inoculation method, stumps covered and uncovered with dark plastic bags were used to verify the coverage effect on creating a suitable environment for fungal development (Fig. 2D).

In inoculation by spraying, a spray bottle containing $25 \mathrm{~mL}$ of the fungal solution was used for each stump (Fig. 2A). For inoculation by drilling, a wood boring drill was used (Fig. 2B) to create a hole in the centre of the stump and four holes perpendicularly distributed at the heartwood-sapwood boundary (Fig. 2C). With a syringe, $5 \mathrm{~mL}$ of the fungal solution was introduced into each hole.

For each fungus, 16 stumps were inoculated: eight stumps for each inoculation method, four of which were covered with a plastic bag. Eight stumps without the fungal solution that had the same coverage and boring situations were used as a control sample.

After four months, degradation of the stumps was evaluated with a dynamic penetrometer (Andrade et al., 2012). Thus, the depth of the resulting penetration of one impact produced by the penetrometer rod was measured. This evaluation was conducted at four points on the stump surface: three distributed at the heartwood-sapwood boundary and one in the centre of the stump.

A Stress Wave Timer was also used to evaluate the degradation of the stumps using the propagation velocity of stress waves. Therefore, a hammer hit and a transducer were used to generate and receive the signal, respectively. In each stump, six measurements distributed in two perpendicular positions were performed without the presence of bark. The propagation velocity of the stress waves $(\mathrm{V})$ was calculated based on the time ( $\mathrm{t}$ ) it took the wave to travel the distance (d) between the transducers using the following equation: $\mathrm{V}=\mathrm{d} / \mathrm{t}$.

\subsection{Analysis and evaluation of the results}

A completely randomized two-way factorial design was used for the accelerated decay test and field test with the isolated fungi. The means and standard deviations were used for the chemical analysis of the decayed wood.

The Scott-Knott test $(\mathrm{p} \leq 0.05)$ was used for the factors and significant interactions detected by the $\mathrm{F}$ test $(\mathrm{p} \leq 0.05)$. The mass loss percentage data (ML) were transformed by arcsin [square root (ML/ 100)] to meet the necessary conditions for the use of parametric tests. 

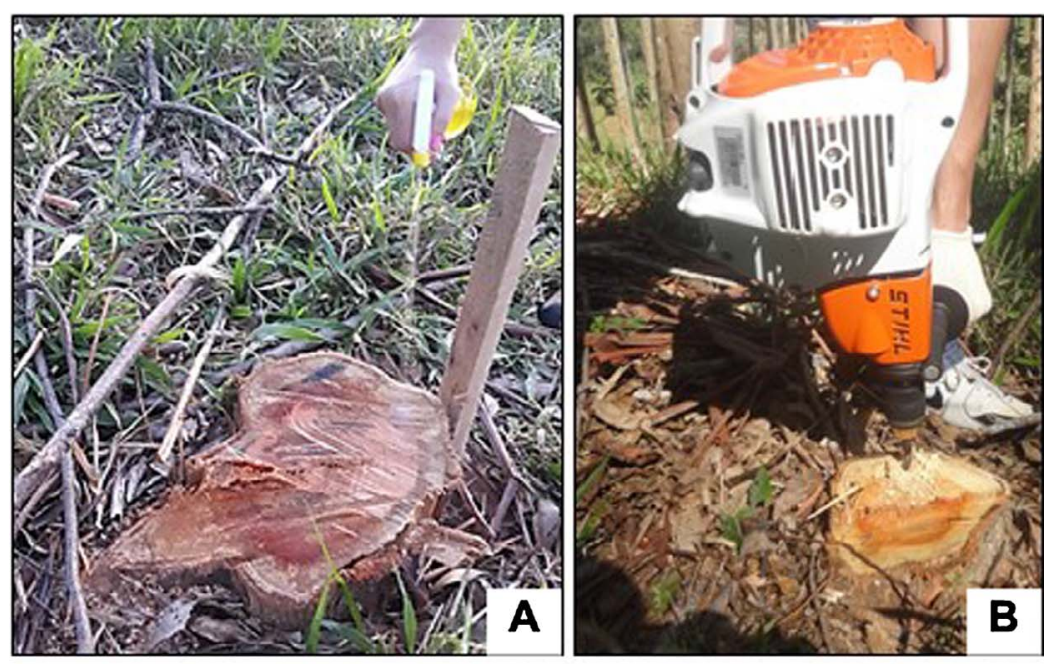

Fig. 2. Assembly steps of the field test: spraying a fungal solution on stumps (A); drilling the stump with a wood boring drill (B); drilled stump (C); and a stump covered with a plastic bag (D).
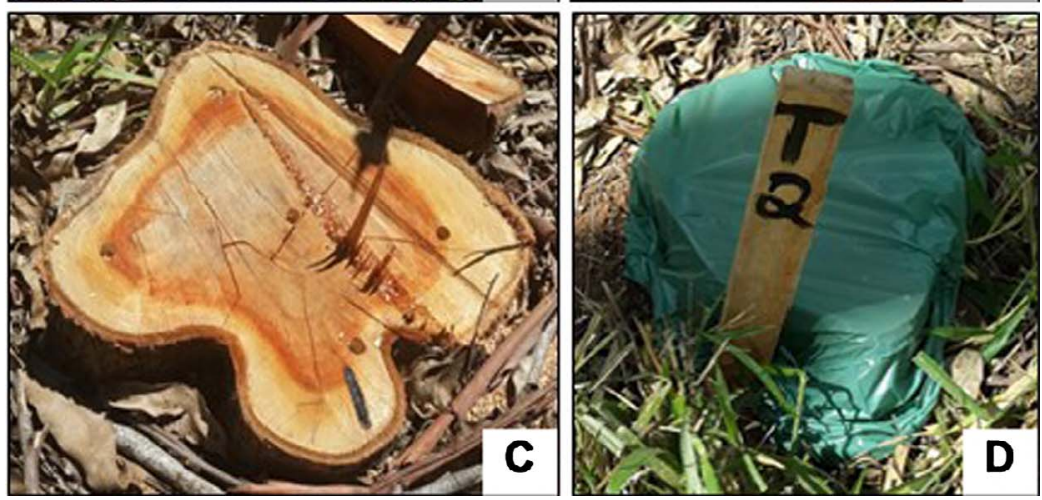

\section{Results and discussion}

\subsection{Accelerated decay test with the isolated fungi}

Significant differences among the fungi, wood position and interaction between the fungi $\mathrm{x}$ wood position were indicated by analysis of variance. In the comparison of the mass loss for each fungus among the positions tested (Table 2), the fungi G. trabeum, P. placenta, P. fumosus, $P$. chrysosporium, Penicillium sp. and $P$. implicatum did not differ among the wood positions, indicating that different positions did not influence degradation by these fungi.

However, the wood positions showed significant differences for the other fungi tested, with the heartwood-sapwood boundary showing the greatest mass loss. Significant differences for all of the positions tested were found only for Acremonium sp., which showed a reduction in mass loss in the middle and inner heartwood of $44.31 \%$ and $57.88 \%$, respectively, in comparison to the heartwood-sapwood boundary position (Table 2).

The effect of the wood position on the fungal decay potential was observed by Bhat et al. (2005), Moya and Berrocal (2010) and Paes et al. (2015). Generally, degradation by wood-destroying organisms is higher at external positions that contain sapwood. However, for some of the fungi tested, it was observed that the internal positions were deteriorated similarly to the external ones, indicating their potential for the deterioration of stumps.

In the comparison of mass loss for each wood position, there were no significant differences among the fungi $G$. trabeum, $P$. placenta and Acremonium sp. at the heartwood-sapwood boundary position (Table 2).

Table 2

Comparison between the average mass loss due to the wood position and tested fungi with their respective degradation classes.

\begin{tabular}{|c|c|c|c|c|c|c|}
\hline \multirow[t]{2}{*}{ Fungus } & \multicolumn{6}{|l|}{$\begin{array}{l}\text { Mass loss (\%) } \\
\text { Wood position }\end{array}$} \\
\hline & H-S boundary & Degrad. class ${ }^{\mathrm{a}}$ & Middle heartwood & Degrad. class & Inner heartwood & Degrad. class \\
\hline G. trabeum & $32.62 \mathrm{aA}$ & $\mathrm{D}$ & $31.84 \mathrm{aA}$ & $\mathrm{D}$ & $37.02 \mathrm{aA}$ & $\mathrm{D}$ \\
\hline P. placenta & $32.77 \mathrm{aA}$ & $\mathrm{D}$ & $33.46 \mathrm{aA}$ & $\mathrm{D}$ & $34.63 \mathrm{aA}$ & $\mathrm{D}$ \\
\hline P. fumosus & $20.25 \mathrm{bA}$ & MD & $17.31 \mathrm{bA}$ & MD & $19.76 \mathrm{bA}$ & MD \\
\hline Acremonium sp & $28.52 \mathrm{aA}$ & $\mathrm{D}$ & $15.88 \mathrm{bB}$ & MD & $12.01 \mathrm{cC}$ & MD \\
\hline P. chrysosporium & $11.30 \mathrm{cA}$ & $\mathrm{MD}$ & $10.31 \mathrm{cA}$ & SD & $11.14 \mathrm{cA}$ & MD \\
\hline Cladosporium sp. & $10.20 \mathrm{cA}$ & $\mathrm{SD}$ & $2.57 \mathrm{~dB}$ & SD & $3.06 \mathrm{~dB}$ & $\mathrm{SD}$ \\
\hline T. citrinoviride & $7.41 \mathrm{dA}$ & SD & $2.67 \mathrm{~dB}$ & SD & $2.10 \mathrm{~dB}$ & SD \\
\hline R. confertum & $5.73 \mathrm{dA}$ & SD & $2.48 \mathrm{~dB}$ & SD & $2.62 \mathrm{~dB}$ & SD \\
\hline Penicillium sp & $0.69 \mathrm{eA}$ & SD & $0.97 \mathrm{eA}$ & SD & $0.41 \mathrm{eA}$ & SD \\
\hline P. implicatum & $0.55 \mathrm{eA}$ & SD & $0.27 \mathrm{eA}$ & SD & $0.79 \mathrm{eA}$ & SD \\
\hline
\end{tabular}

Means followed by the same lowercase (column) or uppercase (line) letter do not differ (Scott-Knott $\mathrm{p}>0.05$ ).

${ }^{a}$ SD: Slightly degrading, MD: Moderately degrading, D: Degrading. 
The mass loss caused by Acremonium sp. was similar to that of the wood-decaying fungi with recognized potential (G. trabeum and $P$. placenta), making it a promising fungus for the degradation of stumps. Silva et al. (2014) studied the potential of Acremonium sp. (basidiomycete 1) to decay eucalyptus wood and found an average mass loss of $28.43 \%$ at the sapwood position, which was similar to the results found in this study.

Among all of the fungi isolated in this study, $P$. chrysosporium and Cladosporium sp. showed the best performances and did not differ from each other at the heartwood-sapwood boundary position, with mass losses that were $65.51 \%$ and $68.87 \%$ lower compared to P. placenta (Table 2), respectively.

At the middle heartwood position, the fungi G. trabeum and P. placenta again caused the greatest mass loss, differing from the other fungi. Deteriorations caused by $P$. fumosus and Acremonium sp. were similar and were greater than that caused by $P$. chrysosporium. Compared to Acremonium sp., $P$. chrysosporium showed a reduction of $35.07 \%$ in its decay potential (Table 2).

$G$. Trabeum and P. placenta caused the highest mass loss in the inner heartwood, followed by $P$. fumosus. At the same wood position, Acremonium sp. showed a decay potential that was $7.24 \%$ higher than that of $P$. chrysosporium; however, no significant differences were found (Table 2). Silva et al. (2014) found an average mass loss of $5.48 \%$ in eucalyptus heartwood deteriorated by Acremonium sp. (Basidiomycete 1 ), which is lower than the value found in this study.

In addition to Acremonium sp., $P$. chrysosporium also showed decay potential, since their average mass losses did not vary among the wood positions.

It was also found that $G$. trabeum and $P$. placenta were classified as degrading at all positions. Acremonium sp. was considered to be degrading only at the heartwood-sapwood boundary position and was classified as moderately degrading at the other wood positions. The fungus $P$. chrysosporium was also classified as moderately degrading at the boundary and inner positions, while it was classified as slightly degrading at the middle heartwood position (Table 2).

The low degradation caused by the fungus $T$. citrinoviride can be explained by the fact that the decay test conducted is specific for brown- and white-rot fungi and the fungi of this genus are reported in the literature as causing soft-rot (Shrestha et al., 2009). Therefore, it would be necessary to conduct specific tests for these fungi to obtain their effective decay potential.

\subsection{Chemical analysis}

The fungi $R$. confertum, Acremonium sp., $P$. chrysosporium, Cladosporium sp. and T. citrinoviride showed the highest mass loss in the accelerated decay test, and the test samples decayed by these fungi were used in the chemical analysis, which indicated changes in the chemical composition of decayed wood (Table 3).

In the control samples, the highest proportion of extractives was obtained at the heartwood-sapwood boundary position. According to Hillis (1971), the higher content found in this region is caused by fresh biochemical changes of reserve substances.

An increase in the total extractive content was observed at the heartwood-sapwood boundary position that was decayed by Acremonium sp., P. chrysosporium and Cladosporium sp. compared to the control samples. This increase (32\%) can be explained by the highest mass loss caused by these fungi, promoting a higher amount of breakdown and increasing the solubility of the major components of wood.

In addition to changes in the major components of wood, biological degradation of wood can also increase the content of soluble extractives due to the increase of free sugars, which is caused by the enzymatic action of fungi on hemicellulose (Silva et al., 2014). These authors also stated that this increase can vary with the deterioration level and type of fungi tested. Istek (2006) and Malakani et al. (2014) also found an increase in wood extractives in response to a fungal attack, attributing this fact to the breakdown of cell wall constituents, increasing the solubility of extractives by the employed solvents.

Changes in extractives caused by fungi in the middle and inner heartwood were lower compared to control samples, which may be explained due to the lowest mass loss at these wood positions, except for with the fungus $P$. chrysosporium, which caused an increase in the content of extractives at these positions (Table 3). As shown in Table 2, only P. chrysosporium showed no significant differences at these wood positions; therefore, its behaviour with regard to the extractives was similar at the different positions tested.

In terms of the total lignin content, no variations among the positions tested were observed in the control samples. Overall, a decrease in the total lignin content was observed at the heartwood-sapwood boundary position, where the highest mass loss occurred. The lowest values of the total lignin content at this position were observed in wood decayed by $R$. confertum, Acremonium sp., and P. chrysosporium, with reductions of $10.95,10.61$, and $13.21 \%$, respectively, compared to control samples, while Cladosporium sp. and T. citrinoviride promoted reductions of 5.64 and $8 \%$, respectively, compared to control samples (Table 3).

Table 3

Chemical composition of samples after fungal attack in an accelerated decay test.

\begin{tabular}{|c|c|c|c|c|c|}
\hline Fungus & Wood positions & Mass loss (\%) & Total extractives (\%) & Total lignin (\%) & Holocellulose (\%) \\
\hline \multirow[t]{3}{*}{ R. confertum } & H-S bound. & 5.73 & $2.57(0.02)$ & $28.37(0.39)$ & $70.34(1.43)$ \\
\hline & Middle heart. & 2.48 & $2.76(0.05)$ & $32.18(2.06)$ & $65.06(2.10)$ \\
\hline & Inner heart. & 2.62 & $3.10(0.03)$ & $32.47(0.28)$ & $64.43(0.31)$ \\
\hline \multirow[t]{3}{*}{ Acremonium sp. } & H-S bound. & 28.52 & $4.82(0.67)$ & $28.48(0.33)$ & $66.71(1.00)$ \\
\hline & Middle heart. & 15.88 & $2.78(0.03)$ & $32.08(0.18)$ & $65.14(0.15)$ \\
\hline & Inner heart. & 12.01 & $2.04(0.30)$ & $30.67(0.30)$ & $67.30(0.61)$ \\
\hline \multirow[t]{3}{*}{ P. chrysosporium } & H-S bound. & 11.30 & $4.85(0.42)$ & $27.65(0.47)$ & $67.50(0.05)$ \\
\hline & Middle heart. & 10.31 & $5.41(0.56)$ & $29.92(1.75)$ & $64.67(2.22)$ \\
\hline & Inner heart. & 11.14 & $5.71(0.42)$ & $30.97(0.18)$ & $63.32(0.38)$ \\
\hline \multirow[t]{3}{*}{ Cladosporium sp. } & H-S bound. & 10.20 & $4.66(0.07)$ & $30.06(1.13)$ & $65.28(1.20)$ \\
\hline & Middle heart. & 2.57 & $2.41(0.49)$ & $32.61(0.65)$ & $64.98(0.16)$ \\
\hline & Inner heart. & 3.06 & $2.81(0.22)$ & $31.57(0.28)$ & $65.61(0.49)$ \\
\hline \multirow[t]{3}{*}{ T. citrinoviride } & H-S bound. & 7.41 & $3.76(0.04)$ & $29.31(0.23)$ & $66.93(0.20)$ \\
\hline & Middle heart. & 2.67 & $2.44(0.40)$ & $34.06(1.31)$ & $63.50(1.70)$ \\
\hline & Inner heart. & 2.10 & $2.69(0.49)$ & 32.73 (1.89) & $64.58(2.38)$ \\
\hline \multirow[t]{3}{*}{ Control } & H-S bound. & - & $3.61(0.67)$ & $31.86(1.96)$ & $64.53(2.62)$ \\
\hline & Middle heart. & - & $2.99(0.15)$ & $31.71(0.89)$ & $65.30(0.75)$ \\
\hline & Inner heart. & - & $2.21(0.19)$ & $33.03(0.03)$ & $64.63(0.02)$ \\
\hline
\end{tabular}

* Numbers in parentheses are standard deviations. 
Table 4

Comparison between the average penetration due to fungi and treatments tested.

\begin{tabular}{|c|c|c|c|c|}
\hline \multirow{3}{*}{ Fungus } & \multicolumn{4}{|c|}{$\begin{array}{l}\text { Penetration }(\mathrm{cm}) \\
\text { Inoculation methods }\end{array}$} \\
\hline & \multicolumn{2}{|l|}{ Drilling } & \multicolumn{2}{|l|}{ Spraying } \\
\hline & $\begin{array}{l}\text { Covered } \\
\text { stumps }\end{array}$ & $\begin{array}{l}\text { Uncovered } \\
\text { stumps }\end{array}$ & $\begin{array}{l}\text { Covered } \\
\text { stumps }\end{array}$ & $\begin{array}{l}\text { Uncovered } \\
\text { stumps }\end{array}$ \\
\hline P. implicatum & $1.11 \mathrm{bB}$ & $1.05 \mathrm{bB}$ & $1.25 \mathrm{aA}$ & $1.26 \mathrm{aA}$ \\
\hline R. confertum & $1.18 \mathrm{bA}$ & $1.11 \mathrm{bA}$ & $1.26 \mathrm{aA}$ & $1.18 \mathrm{aA}$ \\
\hline Acremonium sp. & $1.23 \mathrm{aA}$ & $1.30 \mathrm{aA}$ & $1.26 \mathrm{aA}$ & $1.20 \mathrm{aA}$ \\
\hline P. chrysosporium & $1.15 \mathrm{bB}$ & $1.15 \mathrm{bB}$ & $1.34 \mathrm{aA}$ & $1.25 \mathrm{aA}$ \\
\hline Cladosporium sp. & $1.30 \mathrm{aA}$ & $1.21 \mathrm{aB}$ & 1.14 bB & $1.18 \mathrm{aB}$ \\
\hline Penicillium sp. & $1.21 \mathrm{bA}$ & $1.21 \mathrm{aA}$ & $1.10 \mathrm{bA}$ & $1.12 \mathrm{aA}$ \\
\hline T. citrinoviride & $1.30 \mathrm{aA}$ & $1.17 \mathrm{aB}$ & $1.06 \mathrm{bB}$ & $1.27 \mathrm{aA}$ \\
\hline Control & $1.17 \mathrm{bA}$ & $1.21 \mathrm{aA}$ & $1.27 \mathrm{aA}$ & $1.26 \mathrm{aA}$ \\
\hline
\end{tabular}

Means followed by the same lowercase (column) or uppercase (line) letter do not differ (Scott-Knott $\mathrm{p}>0.05$ ).

The lowest values of the total lignin content at all of the tested positions was obtained by $P$. chrysosporium compared to control samples, indicating its preference for lignin. According to El-Gammal et al. (1995) and Istek et al. (2005), the fungus $P$. chrysosporium has special enzymes that are highly selective for lignin, while cellulose is slightly changed. Istek et al. (2005) studied the degradation of Abies bornmülleriana and Fagus orientalis by the white-rot fungus $P$. chrysosporium and found significant losses in the lignin content. Compared to control samples these losses represented $15 \%$ and $23 \%$ reductions, respectively.

Silva et al. (2014) studied the decay potential of two basidiomycetes isolated from 5- to 6-year-old decayed eucalyptus stumps and found $10 \%$ and $2 \%$ reductions in the lignin content of $E$. grandis $\times$ urophyla sapwood and heartwood, respectively, which is close to the results found in this study for Acremonium sp.

No reduction in the holocellulose content was observed compared to control samples, indicating the selectivity or preference of the isolated fungi for lignin. According to Ferraz et al. (2008) and Jawjit et al. (2007), fungi with this selectivity can be used for biopulping, which consists of treating wood chips used in the paper industry with lignindegrading fungi. This biological pre-treatment increases the susceptibility of lignin to solubilization by pulping liquor, facilitates defibrillation and pulp refining, and results in savings of reagents and energy.

\subsection{Deterioration of stumps by isolated fungi}

\subsubsection{Decay evaluation using a dynamic penetrometer}

Significant differences of the penetration depth values among the fungi tested and the interaction between fungi and inoculation methods were indicated by analysis of variance. In the comparison between fungi inoculated in drilled and covered stumps (Table 4), only Acremonium sp., Cladosporium sp. and T. citrinoviride promoted penetration averages that were significantly higher than the control samples, which did not differ from each other. For these fungi, the levels of penetration achieved in the stumps were $5 \%, 11 \%$ and $11 \%$, respectively, which were higher than the control stumps.

For the drilled and uncovered stumps, the highest depth achieved by the dynamic penetrometer was for stumps inoculated with Acremonium sp. The average depth reached was $7.4 \%$ higher compared to the control stump, although there was no significant difference. Similar to the above observation, in the treatments in which fungi were inoculated by spraying, in both covered and uncovered stumps, the higher average penetration did not differ from control samples (Table 4).

Comparing the inoculation methods for each fungus tested, higher averages for $P$. implicatum and $P$. chrysosporium were achieved in inoculation of stumps by spraying and were not influenced by the coverage conditions. These averages were $16.2 \%$ ( $P$. implicatum) and $12.6 \%$ ( $P$. chrysosporium) higher compared to the treatment with drilled stumps. This fact can be explained by the higher contact area covered by the spraying method, while the other inoculation method remained concentrated near the holes.

No significant differences were found between the treatments for the fungi $R$. confertum, Acremonium sp., and Penicillium sp. and control stumps. For Cladosporium sp., treatment with drilled and covered stumps obtained the highest penetration average, which was $10.5 \%$ higher compared to the other treatments employed. Regarding the fungus $T$. citrinoviride, treatments with drilled and covered stumps as well as with sprayed and uncovered stumps were statistically similar and superior to the other treatments (Table 4).

Regardless of the treatment used, a deeper penetration was expected when the stumps were covered as this treatment presents a suitable environment for fungal development. However, deeper penetration was only observed in the drilled stumps inoculated with Acremonium sp., Cladosporium sp. and T. citrinoviride.

Andrade et al. (2012) used a dynamic penetrometer to evaluate the potential of isolated fungi for biological stump removal and observed that stumps inoculated with the fungus Pycnoporus sanguineus, which is known for its degradation capability, showed similar results compared to control samples. However, when the stumps were covered, the fungi employed were able to reduce resistance to the penetrometer impact, indicating that the use of a cover provided a suitable environment for fungal development.

\subsubsection{Decay evaluation using a stress wave timer}

No significant differences were found in statistical analysis for stress wave propagation. The averages of the propagation velocities of stress waves $\left(\mathrm{m} \mathrm{s}^{-1}\right)$ are presented in Table 5. Overall, despite the presence of fungal colonization in the stumps (Fig. 3), the changes promoted by the treatments tested were similar to those of the control stumps. Inoculated stumps were expected to be less resistant than control samples after four months of exposure, and the higher propagation velocity of stress waves will be able to confirm their degradation once the stress wave method is capable of detecting sensitive changes in wood decayed by fungi (Teles, 2014).

The propagation velocity of the stress waves in the decayed wood tends to be higher than in healthy wood. When propagated in wood, the waves move along the damaged tissue and its empty spaces, determining its internal condition. Thus, an increase in propagation velocity directly reflects a loss in mechanical strength of wood, indicating increased decay (Zabel and Morrell, 1992; Teles, 2014).

According to Reis and Reis (1997) and Coder (2014), because it is a biological material, the remaining stump is subject to the variation of 
Table 5

Comparison between the average propagation velocity of stress waves due to the fungi and treatments tested.

\begin{tabular}{|c|c|c|c|c|}
\hline \multirow{3}{*}{ Fungus } & \multicolumn{4}{|c|}{$\begin{array}{l}\text { Propagation velocity of stress waves }\left(\mathrm{m} \mathrm{s}^{-1}\right) \\
\text { Inoculation methods }\end{array}$} \\
\hline & \multicolumn{2}{|l|}{ Drilling } & \multicolumn{2}{|l|}{ Spraying } \\
\hline & Covered stumps & $\begin{array}{l}\text { Uncovered } \\
\text { stumps }\end{array}$ & Covered stumps & $\begin{array}{l}\text { Uncovered } \\
\text { stumps }\end{array}$ \\
\hline P. implicatum & 348.34 (27.55) & $310.69(61.62)$ & $347.46(10.74)$ & $310.80(55.50)$ \\
\hline R. confertum & $295.72(62.81)$ & $346.98(88.56)$ & $302.30(19.45)$ & 324.97 (36.18) \\
\hline Acremonium sp. & $304.90(15.75)$ & 320.63 (25.47) & $308.72(25.40)$ & 337.66 (19.14) \\
\hline P. chrysosporium & $319.32(6.89)$ & $342.69(59.50)$ & $289.85(38.47)$ & 313.24 (95.06) \\
\hline Cladosporium sp. & $365.73(54.97)$ & $377.99(68.08)$ & 364.50 (43.47) & $301.48(33.25)$ \\
\hline Penicillium sp. & $279.57(23.47)$ & $292.63(22.73)$ & $291.85(16.48)$ & $332.22(66.21)$ \\
\hline T. citrinoviride & $321.58(34.87)$ & $295.55(28.68)$ & 360.35 (61.92) & $292.75(46.34)$ \\
\hline Control & 374.27 (25.39) & $287.73(2.40)$ & $364.70(92.66)$ & $340.06(40.66)$ \\
\hline
\end{tabular}

* Numbers in parentheses are standard deviations.
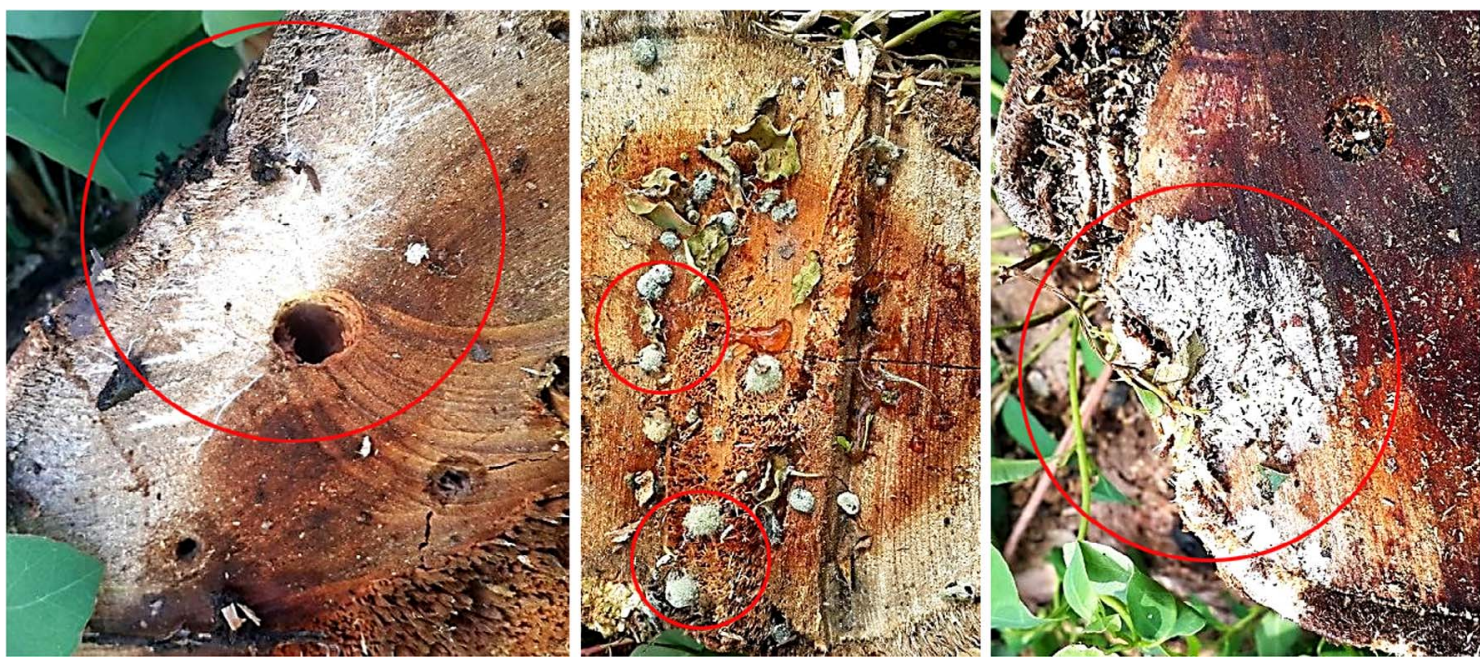

Fig. 3. Visual signs of fungal colonization in the inoculated stumps.

its resistance to wood-destroying organisms, which varies with environmental conditions and the characteristics of the wood. The death of a stump has a fundamental importance in its deterioration process and may be linked to soil and climate conditions. These authors emphasize that the reduction of the physiological vigour of the remaining stumps is more intense in poor soils and dry seasons.

The above-mentioned authors also highlight that the physiological vigour of the remaining stumps can last after the tree is cut and can induce the growth of adventitious points. While physiological activity is still present, a number of defence mechanisms are active, which can delay the appearance of pests and progress of deterioration until the stump vigour is reduced.

Regardless of the treatments tested, the presence of sprouting was observed in some stumps during the field test, indicating their physiological vigour. Due to the above facts, the development and advancement of deterioration in stumps may have been impaired, requiring more exposure time than used in this study to allow stump death or the use of techniques and products to accelerate the death in the remaining stumps.

\section{Conclusions}

Among the fungi isolated from eucalyptus stumps, Acremonium sp. showed the best potential, similar to fungi with recognized deterioration capabilities. Although not as expressive, the isolated fungi $P$. chrysosporium and Cladosporium sp. also showed a decay potential.

The selectivity of fungi isolated by lignin was observed, highlighting their potential for use in studying biopulping. Although the visual presence of fungi was observed in the stumps, no significant variations were observed in the field test. The short period of exposure and physiological vigour of the stumps may have contributed to this result and should be observed for further studies. Biological stump removal shows both environmental and economic potential and needs to be thoroughly studied.

\section{References}

Alonso, S.K., Silva, A.G., Kasuya, M.C.M., Barros, N.F., Cavallazzi, J.R.P., Bettucci, L. Lupo, S., Alfenas, A.C., 2007. Isolation and screening of wood white rot fungi from Eucalyptus spp. forests with potential for use in degradation of stumps and roots. Rev. Árvore 31, 145-155. http://dx.doi.org/10.1590/S0100-67622007000100016.

de Andrade, F.A., Calonego, F.W., Severo, E.T.D., Furtado, E.L., 2012. Selection of fungi for accelerated decay in stumps of Eucalyptus spp. Biores. Technol. 110, 456-461. http://dx.doi.org/10.1016/j.biortech.2012.01.069.

American Society for Testing and Materials - ASTM D-2017, 2005. Standard method of accelerated laboratory test of natural decay resistance of woods. Annu. Book ASTM Stand. 410, 1-5.

Bari, E., Nazarnezhad, N., Kazemi, S.M., Tajick Ghanbary, M.A., Mohebby, B., Schmidt, O., Clausen, C.A., 2015. Comparison between degradation capabilities of the white rot fungi Pleurotus ostreatus and Trametes versicolor in beech wood. Int. Biodeterior. Biodegrad. 104, 231-237. http://dx.doi.org/10.1016/j.ibiod.2015.03.033.

Bhat, K.M., Thulasidas, P.K., Maria Florence, E.J., Jayaraman, K., 2005. Wood durability of home-garden teak against brown-rot and white-rot fungi. Trees - Struct. Funct. 19, 
654-660. http://dx.doi.org/10.1007/s00468-005-0429-0.

Coder, K. D., 2014. Arboriculture Series: Stump Removal in Landscapes. Univ. of Georgia, Warnell School of Forestry and Natural Resources, Publication WSFNR14-8, 27pp.

da Costa, L.G., 2014. Selection of fungi with capacity of degradation in stumps of Eucalyptus spp. for use in biological stump removal. Federal University of Espírito Santo.

Dedecek, R.A., Gava, J.L., 2005. Influence of soil compaction on eucalyptus coppice productivity. Rev. Árvore 29, 383-390. http://dx.doi.org/10.1590/S010067622005000300005.

Dias, A.C., Arroja, L., 2012. Environmental impacts of eucalypt and maritime pine wood production in Portugal. J. Clean. Prod. 37, 368-376. http://dx.doi.org/10.1016/j. jclepro.2012.07.056.

El-Gammal, A.A., Nagleb, Z.A., Helmy, S.M., 1995. Ultrastructural aspects of lignocellulose degradation by some microorganisms. Polym. Degrad. Stab. 50, 199-202.

Ferraz, A., Guerra, A., Mendonça, R., Masarin, F., Vicentim, M.P., Aguiar, A., Pavan, P.C., 2008. Technological advances and mechanistic basis for fungal biopulping. Enzyme Microb. Technol. 43, 178-185. http://dx.doi.org/10.1016/j.enzmictec.2007.10.002.

Goldschimid, O., 1971. Ultraviolet spectra. In: Lignins: Occurrence, Formation, Structure and Reactions. J. Wiley, New York, pp. 241-298.

Gomide, J.L., Demuner, B.J., 1986. Determinação do teor de lignina em material lenhoso: método Klarson modificado. O Pap. 47, 36-38.

Hillis, W.E., 1971. Distribution, properties and formation of some wood extractives. Wood Sci. Technol. 5, 272-289. http://dx.doi.org/10.1007/BF00365060.

Indústria Brasileira de Árvores (IBÁ), 2016. Ibá report 2016. Base Year 2015.

Istek, A., Sivrikaya, H., Eroglu, H., Gulsoy, S.K., 2005. Biodegradation of Abies bornmülleriana (Mattf.) and Fagus orientalis (L.) by the white rot fungus Phanerochaete chrysosporium. Int. Biodeterior. Biodegrad. 55, 63-67. http://dx.doi.org/10.1016/j.ibiod. 2004.07.002.

Istek, A., 2006. Effect of Phanerochaete chrysosporium white rot fungus on the chemical composition of Populus tremula L. Cellulose Chem. Technol. 40 (6), 475-478.

Jawjit, W., Kroeze, C., Soontaranun, W., Hordijk, L., 2007. Options to reduce the environmental impact by eucalyptus-based Kraft pulp industry in Thailand: model description. J. Clean. Prod. 15, 1827-1839. http://dx.doi.org/10.1016/j.jclepro.2006. 10.003.

Malakani, M., et al., 2014. Influence of fungal decay on chemi-mechanical properties of beech wood (Fagus orientalis). Cellulose Chem. Technol. 48 (1-2), 97-103.

Moya, R., Berrocal, A., 2010. Wood colour variation in sapwood and heartwood of young trees of Tectona grandis and its relationship with plantation characteristics, site, and decay resistance. Ann. For. Sci. 67, 109-118. http://dx.doi.org/10.1051/forest/ 2009088.

Negrão, D.R., da Silva Júnior, T.A.F., Passos, J.R. de S., Sansígolo, C.A., Minhoni, M.T. de A., Furtado, E.L., 2014. Biodegradation of Eucalyptus urograndis wood by fungi. Int. Biodeterior. Biodegrad. 89, 95-102. http://dx.doi.org/10.1016/j.ibiod.2014.01.004.

Paes, J.B., Brocco, V.F., Moulin, J.C., Motta, J.P., Alves, R.C., 2015. Efeitos dos extrativos e da densidade na resistência natural de madeiras ao térmita Nasutitermes corniger. Cerne 21, 569-578. http://dx.doi.org/10.1590/01047760201521041849.

Reis, G.G. dos, Reis, M. das G.F., 1997. Fisiologia da brotação de eucalipto com ênfase nas suas relações hídricas. Piracicaba.

Ryss, A.Y., Kulinich, O.A., Sutherland, J.R., 2011. Pine wilt disease: a short review of worldwide research. For. Stud. China 13, 132-138. http://dx.doi.org/10.1007/ s11632-011-0205-8.

Shrestha, P., Khanal, S.K., Pometto, A.L., van Leeuwen, J.H., 2009. Enzyme production by wood-rot and soft-rot fungi cultivated on corn fiber followed by simultaneous saccharification and fermentation. J. Agric. Food Chem. 57, 4156-4161. http://dx.doi. org/10.1021/jf900345n.

TAPPI, 1992. T 257 om-92: sampling and preparing wood for analysis, in: Test Methods 1992-1993. Tappi Technology Park, Atlanta.

TAPPI, 1996. T 264 om-88: preparation of wood for chemical analysis. In: Test Methods 1996-1997. Tappi Technology Park, Atlanta.

Schmidt, O., 2006. Wood and Tree Fungi: Biology, Damage, Protection, and Use. Springer-Verlag, Berlin doi: 10.1007/3-540-32139-X.

da Silva, G.A., Marino, R.H., Lopes, M.E.G., Almeida, T.Á., Costa, Â.C.F., Martins, M.V.G., 2010. Evaluating the degradation potential of white rot fungi. Rev. Bras. Ciências Agrárias 5, 225-231.

da Silva, L.F., Paes, J.B., de Jesus Junior, W.C., Oliveira, J.T. da S., Furtado, E.L., Alves, F.R., 2014. Deterioration of Eucalyptus spp. wood by xylophagous fungi. Cerne 20, 393-400. http://dx.doi.org/10.1590/01047760201420031462.

Teles, R.F., 2014. Nondestructive tests to evaluate the perfomance of treated amazonian woods. Universidade de Brasília.

Tian, B.-Y., Huang, Q.-G., Xu, Y., Wang, C.-X., Lv, R.-R., Huang, J.-Z., 2010. Microbial community structure and diversity in a native forest wood-decomposed hollow-stump ecosystem. World J. Microbiol. Biotechnol. 26, 233-240. http://dx.doi.org/10.1007/ s11274-009-0165-5.

Zabel, R.A., Morrell, F.L., 1992. Wood Microbiology: Decay and Its Prevention. Academic Press, San Diego. 